Pinter: Climatic Factors, Reproduction Success and Populations Dynamics i

\title{
CLIMATIC FACTORS, REPRODUCTION SUCCESS AND POPULATIONS DYNAMICS IN THE MONTANE VOLE MICROTUS MONTANUS
}

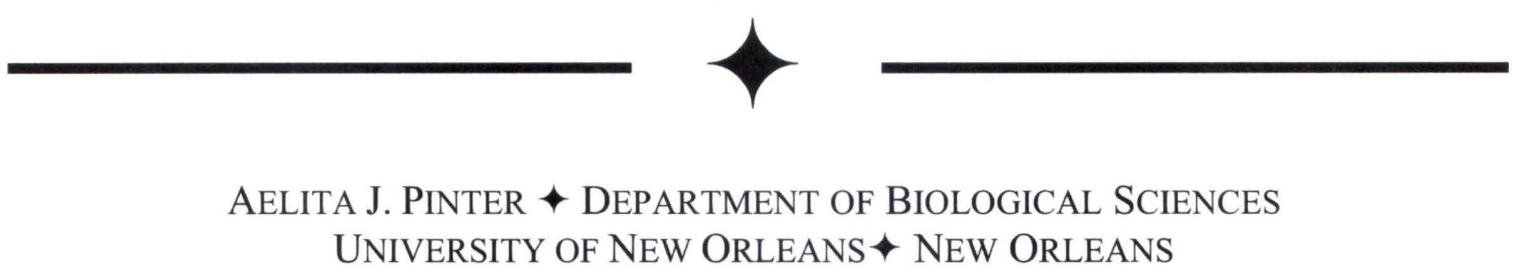

\section{$\downarrow$ OBJECTIVES}

A variety of hypotheses has been proposed to explain multiannual fluctuations in population density ("cycles") of small rodents (for reviews see Finerty 1980, Taitt and Krebs 1985). Doubtless, such cycles - known since antiquity (Elton 1942) - result from an interaction of a multitude of factors. However, the inability of extant hypotheses, alone or in combination, to explain the causality of cycles rests in no small measure with the fact that longterm studies of the phenomenon are notoriously uncommon.

The objectives of this project are to continue the long-term study of population dynamics of the montane vole, Microtus montanus, in Grand Teton National Park. Earlier observations (Negus et al. 1992,Pinter 1986, 1988) indicate that environmental variables might contribute to the population density cycles of these rodents, possibly by influencing their growth and various aspects of their reproduction.

\section{$\downarrow$ MeTHODS}

In 2006 Microtus montanus were livetrapped at two times of the year: the second half of May (spring study period) and mid-July to mid-August (summer study period). Animals were killed with an overdose of Metofane as soon as possible after capture. They were aged using weight, total length and pelage characteristics. Reproductive organs, the spleen and the adrenal glands were collected from all animals and preserved in Lillie's neutral buffered formalin for further histological study. Flat skins were prepared from all animals.

Population density was estimated on the basis of trapping success in a permanent grid (established in 1970). The grid consists of 121 stations placed in a square, $5 \mathrm{~m}$ apart, 11 stations $(50 \mathrm{~m})$ on a side. Each station is marked with a stake. Trapping in this grid was performed only during the summer study period. One unbaited Sherman livetrap was set at each station. Additional trapping was carried out in nearby meadows away from the grid to obtain additional females for litter size determination.

During the spring study period trapping was carried out at a number of sites, all of them well removed from the permanent grid. The purpose of this was to leave the grid site as undisturbed as possible since the grid was the major source of information on population density. The main objective of the spring study period was to determine (on the basis of embryo size) the onset of reproduction on a populationwide basis. This information is very important for two major reasons: (1) onset of reproduction in M. montanus in Grand Teton National Park can vary by as much as 40 days among years, and (2) the time at which reproduction begins has significant repercussions on the productivity of the population for the year.

Weather data were obtained from records at the Jackson Lake Dam. Although Moran $5 \mathrm{WNW}$ is not a Class A weather station, it is located less than $2 \mathrm{~km}$ from the permanent grid. Data collected included temperature, 
precipitation, and the date of complete spring melt-off.

\section{$\downarrow \quad$ RESUlTS AND DISCUSSION}

In 2006, in Grand Teton National Park, populations of Microtus montanus exhibited a dramatic decline in numbers. Indeed, the population fell to the lowest level documented within the past decade. The decline appeared to have taken place during the winter of 2005-2006; this could be detected at the very beginning of the 2006 field season. During the spring study period there was virtually no vole sign (cuttings, droppings, runways). Furthermore, trap success during the spring study period was also noteworthy for two reasons: (1) the number of voles trapped was the lowest ever for any spring period within the 37 years of this long-term study, and (2) absolutely no females were trapped. A feature attesting to the unusually low population density was a virtual absence of fighting among the males. There were no bite marks either on their hip glands (the most common target of intraspecific strife among male montane voles) or on any other parts of the body. In years of higher density fighting among males is the rule, resulting in damage such as scarring of the hip glands and of the skin (especially on the rump), torn ears and missing digits.

Since no females were captured during the spring study period, the onset of reproduction within the vole population could not be ascertained from direct observations (e.g., number of females pregnant, stage of pregnancy, presence or absence of lactation). However, one of the many advantages of a long-term study is that gradually parameters become evident that can be used to make reliable correlations. One of these parameters in the spring study period is meltoff, since reproduction in the montane vole in Grand Teton National Park is closely linked to the disappearance of snow cover. The spring of 2006 in Jackson Hole was early; consequently, the onset of reproduction on a population-wide basis must also have been early. In other words, all of the females would have been pregnant; indeed, some of the females were probably already pregnant with their second litter. Since young born before the first week in July can become reproductively active in the year of their birth, the earlier the onset of reproduction in the spring, the larger the numbers of breeders in a given year.
In spite of the early onset of reproduction in the spring, the population densities attained in 2006 were $50 \%$ lower than those in 2005. This represents a second consecutive year of a decline in population density of Microtus montanus. This result is not surprising. First, and probably most importantly: the initial breeding population was exceedingly small - although reasons behind the winter crash of the population remain totally unknown. Second, litter sizes in 2006 were not significantly different from those observed in 2005, yet these litter sizes were being produced by a dramatically smaller breeding population. Third, the general area continued to experience a drought; the consequent early senescence and drying of the preferred food plants of Microtus montanus contributed to an early cessation of reproduction. A simultaneous coincidence of suboptimal parameters led to the dramatic decline in population densities of montane voles in 2006 .

\section{$\downarrow$ CONCLUSIONS}

The fluctuations in the population density of montane voles from year to year are doubtless caused by several poorly understood variables (e.g., diet, climate, disease -Watkins et al. 2006) and equally poorly understood interactions among such variables. The data collected during the 2006 field season clearly demonstrate the critical significance of one of these variables - the size of the breeding population at the onset of the breeding season. In the spring of 2006 this population was exceptionally small. The early onset of reproduction in 2006, although conducive to a rapid growth in population density, was unable to compensate for the near-record low in the population density of the initial breeding population.

\section{$\downarrow$ ACKNOWLEDGEMENTS}

I gratefully acknowledge the availability of the facilities at the University of Wyoming-National Park Service Research Center and the enthusiastic support of the Research Center staff without which it would have been impossible to accomplish this work. I also thank Steven Cain and Megan Callahan for their unfailing cooperation and administrative 
support. I am particularly grateful to the Steering Committee of the UW-NPS Research Center and to the National Park Service for their cognizance of the fact that an understanding of microtine cycles can be gained only from longterm studies in undisturbed habitats.

\section{LITERATURE CITED}

Elton, C. S. 1942. Voles, mice and lemmings. Clarendon Press, Oxford. 496 pp.

Finerty, J. P. 1980. The Population Ecology of Cycles in Small Mammals. Mathematic Theory and Biological Fact. Yale Univ. Press, New Haven. 234 pp.

Negus, N. C., P. J. Berger and A. J. Pinter. 1992. Phenotypic plasticity of the montane vole (Microtus montanus) in unpredictable environments. Canadian Journal of Zoology. 70:2121-2124.
Pinter, A. J. 1986. Population dynamics and litter size of the montane vole, Microtus montanus. Canadian Journal of Zoology. 64:1487-1490.

Pinter, A. J. 1988. Multiannual fluctuations in precipitation and population dynamics of the montane vole, Microtus montanus. Canadian Journal of Zoology 66:2128-2132.

Taitt, M. J. and C. J. Krebs. 1985. Population dynamics and cycles. In: Biology of New Microtus. R. H. Tamarin, ed. Spec. Pub. American Society of Mammalologists. 8:567-620.

Watkins, R. A., S. E. Moshier and A. J. Pinter. 2006. The flea, Megabothris abantis: an invertebrate host of Hepatozoon sp. and a likely definitive host in Hepatozoon infections of the montane vole, Microtus montanus. Journal of Wildlife Diseases, 42:386-390. 